\title{
Bromine and selenium in human aorta
}

\author{
JD CROSS, ${ }^{2}$ RM RAIE, ${ }^{2}$ AND H SMITH ${ }^{1}$ \\ From the ${ }^{1}$ Department of Forensic Medicine and Science, University of Glasgow, and the ${ }^{2}$ Department of \\ Clinical Physics and Bioengineering, Western Regional Hospital Board, West Graham Street, Glasgow \\ G128QQ,UK
}

SUMMARY The bromine and selenium concentrations of healthy and atheromatous human aorta and of other organs are reported. No relation between age and concentration in the aorta is found. The selenium levels of the aorta are similar to those of other internal organs; the content of the three layers show no significant differences. The bromine concentrations of the media are higher than those of the other layers, which are similar to those of the internal organs. A possibly greater concentration of bromine in atheromatous medial tissue is indicated.

Many diseases and malfunctions of the body, such as cancer, coronary heart disease, and multiple sclerosis, have been associated with abnormal trace element concentrations. ${ }^{12}$ Wester, ${ }^{2}$ for example, describes significant increases and decreases in the concentrations of some elements between healthy and injured heart tissue.

During studies of two of the lesser known elements, bromine, ${ }^{3}$ and selenium, ${ }^{4}$ methods for measuring them in human tissue and body fluids were developed. Little is known about the role of bromine in the body, but our findings (Table 1)

Table 1 Bromine content ( $\mu g / g$ dry weight) of human tissue

\begin{tabular}{lrrrrr}
\hline Tissue & No. & Mean & \multicolumn{1}{c}{ SD } & \multicolumn{1}{c}{ Range } & Median \\
\hline Blood & 22 & $21 \cdot 9$ & $6 \cdot 4$ & $10 \cdot 5-33 \cdot 8$ & $22 \cdot 5$ \\
Brain & 22 & $9 \cdot 2$ & $4 \cdot 1$ & $4 \cdot 0-16 \cdot 4$ & $8 \cdot 5$ \\
Heart & 24 & $15 \cdot 4$ & $4 \cdot 6$ & $8 \cdot 4-23 \cdot 4$ & $15 \cdot 1$ \\
Kidney & 24 & $29 \cdot 0$ & $7 \cdot 2$ & $15 \cdot 3-45 \cdot 4$ & $28 \cdot 4$ \\
Liver & 24 & $12 \cdot 0$ & $5 \cdot 5$ & $4 \cdot 5-32 \cdot 1$ & $11 \cdot 8$ \\
Lung & 24 & $35 \cdot 8$ & $14 \cdot 9$ & $3 \cdot 3-63 \cdot 8$ & $34 \cdot 7$ \\
Pancreas & 14 & $13 \cdot 4$ & $7 \cdot 2$ & $3 \cdot 3-29 \cdot 7$ & $13 \cdot 0$ \\
Pectoral muscle & 14 & $9 \cdot 4$ & $6 \cdot 1$ & $1 \cdot 2-25 \cdot 5$ & $7 \cdot 7$ \\
Spleen & 24 & $21 \cdot 8$ & $7 \cdot 6$ & $8 \cdot 3-41 \cdot 0$ & $21 \cdot 9$ \\
Stomach & 14 & $28 \cdot 6$ & $16 \cdot 2$ & $10 \cdot 4-73 \cdot 0$ & $24 \cdot 7$ \\
\hline
\end{tabular}

suggest that it may well be an essential element for man. ${ }^{5}$ The highest bromine levels were found in human aorta, and this tissue showed an unusually broad range of concentrations (6-3-101 ppm dry weight, mean $48 \cdot 4$, standard deviation (SD) $26 \cdot 7$ ppm). This prompted a study to find whether the bromine concentrations in aorta are age-related and which, if any, of the aortic layers is responsible for

Accepted for publication 25 June 1980 accumulating this element. Atherosclerotic aorta tissue was also analysed and compared with healthy tissue.

Fatty material from atherosclerotic lesions is known to contain peroxides of fatty acids, which are not present in healthy tissue ${ }^{6}$ One of the functions of selenium in the body is that of non-specific antioxidant, and it is a constituent of the enzyme that prevents the accumulation of toxic peroxides within the cell. ${ }^{7}$ Peroxides can also be decomposed by selenomethionine, a predominant selenium amino acid in the body. ${ }^{8}$ Since increased selenium in animal feed has been shown to increase the activity of lipid antioxidants ${ }^{9}$ it seemed pertinent to investigate the selenium content of healthy human aorta and to compare this with the levels in diseased material. Layers of healthy intima, media, and adventitia were analysed individually and compared with diseased tissue and plaque regions. Age dependence was also investigated.

\section{Methods}

\section{SAMPLING}

Samples of aorta were collected post mortem from subjects who had died from various causes. Their ages ranged from 1 day to 79 years. They had had no known unusual exposure to bromine or selenium.

The samples were separated visually into those showing atherosclerosis and those that were apparently healthy. The layers of intima, media, and adventitia were separated as far as possible, and the plaque regions were removed and collected.

METHODS OF ANALYSIS

The aortic material was freeze-dried and analysed by 
thermal neutron activation analysis. Bromine was determined instrumentally ${ }^{3}$ with the $777 \mathrm{KeV}$ photopeak of ${ }^{82} \mathrm{Br}$, and selenium was measured by the radiochemical separation technique developed by Raie and Smith. ${ }^{4}$

\section{Results}

Tables 1 and 2 show the levels of bromine and selenium in healthy tissue taken from subjects who had died as a result of violence.

Tables 3 and 4 compare the bromine and selenium concentrations of 'healthy' and diseased aortic tissue.

Table 2 Selenium content ( $\mu g / g d r y$ weight) of human tissue

\begin{tabular}{|c|c|c|c|c|c|}
\hline Tissue & No. & Mean & $S D$ & Range & Medicn \\
\hline Blood & 25 & $0 \cdot 77$ & 0.11 & $0 \cdot 59-1 \cdot 02$ & 0.74 \\
\hline Brain & 13 & $1 \cdot 59$ & $1 \cdot 06$ & $0 \cdot 66-4 \cdot 34$ & $1 \cdot 23$ \\
\hline Hair & 46 & $2 \cdot 24$ & 0.84 & $1 \cdot 27-4 \cdot 11$ & $1 \cdot 96$ \\
\hline Heart & 9 & $1 \cdot 38$ & 0.61 & $0.47-2.44$ & $1 \cdot 43$ \\
\hline Kidney & 8 & $4 \cdot 18$ & $0 \cdot 81$ & $2 \cdot 85-5 \cdot 01$ & $4 \cdot 38$ \\
\hline Liver & 14 & $2 \cdot 47$ & 0.80 & $1 \cdot 50-3 \cdot 83$ & $2 \cdot 54$ \\
\hline L.ung & 8 & $1 \cdot 43$ & 0.63 & $0 \cdot 35-2 \cdot 28$ & $1 \cdot 33$ \\
\hline Spleen & 9 & $1 \cdot 59$ & $0 \cdot 29$ & $1 \cdot 04-1.94$ & $1 \cdot 65$ \\
\hline
\end{tabular}

Table 3 Bromine content ( $\mu g / g d r y$ weight) of human aorta

\begin{tabular}{clccccc}
\hline Type & Tissue & No. & Mean & SD & Range & Median \\
\hline Normal & Intima & 9 & $70 \cdot 6$ & $20 \cdot 8$ & $42 \cdot 9-101$ & $69 \cdot 7$ \\
,$"$ & Media & 9 & $86 \cdot 2$ & $15 \cdot 1$ & $67 \cdot 5-110$ & $90 \cdot 6$ \\
, & Adventitia & 9 & $52 \cdot 3$ & $10 \cdot 9$ & $37 \cdot 9-70 \cdot 5$ & $50 \cdot 5$ \\
Atheroma & Intima & 9 & $64 \cdot 8$ & $38 \cdot 8$ & $21 \cdot 0-127$ & $48 \cdot 8$ \\
$\quad$, & Media & 9 & 104 & $17 \cdot 1$ & $85 \cdot 8-139$ & 103 \\
,$"$ & Adventitia & 9 & $60 \cdot 8$ & $15 \cdot 8$ & $29 \cdot 0-80 \cdot 9$ & $61 \cdot 4$ \\
Total & Intima & 18 & $67 \cdot 7$ & $30 \cdot 4$ & $21 \cdot 0-127$ & $66 \cdot 9$ \\
,$"$ & Media & 18 & $95 \cdot 0$ & $18 \cdot 1$ & $67 \cdot 4-139$ & $94 \cdot 7$ \\
, & Adventitia & 18 & $56 \cdot 5$ & $13 \cdot 9$ & $29 \cdot 0-80 \cdot 9$ & $53 \cdot 4$ \\
\hline
\end{tabular}

Table 4 Selenium contevt ( $\mu g / g d r y$ weight $)$ of human aorta

\begin{tabular}{|c|c|c|c|c|c|c|}
\hline Type & Tissue & No. & Mean & $S D$ & Range & Median \\
\hline \multirow{3}{*}{$\begin{array}{l}\text { Normal } \\
\text { ", } \\
\text { ", }\end{array}$} & Intima & 3 & $1 \cdot 20$ & $0 \cdot 22$ & $0 \cdot 79-1 \cdot 72$ & 1.09 \\
\hline & Media & 3 & 0.96 & 0.02 & $0 \cdot 82-1 \cdot 08$ & 0.98 \\
\hline & Adventitia & 3 & $1 \cdot 07$ & 0.05 & $0 \cdot 87-1 \cdot 32$ & $1 \cdot 01$ \\
\hline \multirow{3}{*}{$\begin{array}{c}\text { Atheroma } \\
\text {," } \\
\text { ", }\end{array}$} & Intima & 6 & $1 \cdot 67$ & 0.68 & $0.93-2 \cdot 78$ & $1 \cdot 58$ \\
\hline & Media & 7 & $1 \cdot 23$ & $0 \cdot 32$ & $0 \cdot 82-1 \cdot 87$ & $1 \cdot 20$ \\
\hline & Adventitia & 7 & 0.95 & 0.43 & $0 \cdot 38-1 \cdot 65$ & 0.92 \\
\hline \multirow{4}{*}{$\begin{array}{c}\text { Total } \\
\text { ", }\end{array}$} & Intima & 9 & $1 \cdot 51$ & 0.63 & $0 \cdot 79-2 \cdot 78$ & $1 \cdot 58$ \\
\hline & Media & 10 & $1 \cdot 15$ & $0 \cdot 30$ & $0 \cdot 82-1 \cdot 87$ & $1 \cdot 10$ \\
\hline & Adventitia & 10 & 0.99 & $0 \cdot 37$ & $0 \cdot 38-1 \cdot 65$ & 0.96 \\
\hline & Plaque & 3 & $1 \cdot 05$ & 0.42 & $0 \cdot 58-1 \cdot 39$ & $1 \cdot 17$ \\
\hline
\end{tabular}

STATISTICAL INTERPRETATION

The Spearman correlation procedure was applied to test for any relation between age and bromine or between age and selenium concentration in the aorta; none was found.

Wilcoxon's sum of ranks test showed the bromine concentration in the media to be significantly higher than that in the intima of adventitia. The selenium content of the three layers showed no significant differences.

After separating aorta showing significant atheroma from visually healthy specimens, Wilcoxon's sum of ranks test was reapplied to the data. The selenium concentrations in the atheromatous tissue were found to be similar to those in the corresponding layers of healthy tissue. The calcific plaque regions were similar in selenium content to the surrounding tissue.

The bromine content of diseased intima and adventitia was found to be indistinguishable from that of healthy tissue. The media, however, showed higher bromine concentrations when atheromatous. Wilcoxon's sum of ranks test showed this to be probably significantly higher, but the small number of samples analysed precludes any more positive interpretation.

\section{Discussion}

The selenium content of the aorta is evenly distributed and is generally similar to that of other internal organs (Table 4). Aorta showing significant atheroma is indistinguishable from visibly healthy tissue in selenium content. This suggests that the build-up of fatty material known as atherosclerosis is unrelated to the selenium content of the tissue.

The bromine concentration in the media is greater than that in the other aortic layers and is possibly higher in atheromatous tissue than in 'healthy' material. Gaunt et al. ${ }^{10}$ have recognised that lipids provide binding sites for bromine, noting a rapid increase in lipid-bound bromine in adipose tissue of rats fed with brominated maize oil. The increased lipid content of the atheromatous lesions could therefore provide a greater number of binding sites for bromine, which might explain the difference between healthy and diseased tissue levels.

The medial layer of human aorta is known to contain age-dependent lipids, which are not found in the other layers, ${ }^{11}$ but since no age relationship was found, the increased bromine content of this layer cannot be specifically associated with these age-dependent lipids.

\section{Conclusion}

For all age groups the media of the aorta contains more bromine than the layers on either side of it, 
and bromine is possibly further concentrated in atheromatous medial tissue, perhaps bound to lipids.

The selenium content of human aorta is similar throughout its layers and is similar to that of most of the internal organs. It neither increases nor decreases with age, and atheroma does not significantly alter its concentration in the aorta. It seems unlikely, therefore, that the build-up of toxic peroxides, which causes atherosclerosis, results from a deficiency of selenium in the aorta.

\section{References}

${ }^{1}$ Schroeder HA. The Poisons Around Us. Bloomington/ London: Indiana University Press, 1974.

2 Wester PO. Trace elements in human myocardial infarction determined by neutron activation analysis. Acta Med Scand 1965;178:765-88.

${ }^{3}$ Cross JD, Smith H. The determination of bromine in biological material by thermal neutron activation analysis. J Radioanalyt Chem 1979;48:191-6.

4 Raie RM, Smith H. The determination of selenium in biological material by thermal neutron activation analysis and atomic absorption spectrometry. $J$ Radioanalyt Chem 1979;48:185-90.

${ }^{5}$ Cross JD, Smith H. Bromine in human tissue. Forensic Sci $1978 ; 11$ :147-53.

- Gonzalez IE, Furman RH. Histochemistry of Spontaneous and Experimental Arterial Lesions-Comparative Atherosclerosis. Eds Roberts JC, Straus R. New York: Harper and Row, 1965.

7 Venugopal B, Luckey TD. Metal Toxicity in Mammals. Vol. 2. New York/London: Plenum Press, 1978.

${ }^{8}$ Olcott HS, Brown WD, van der Veen J. Selenomethionine as an antioxidant. Nature 1961 ;191:1201-2.

- Hamilton JW, Tappel AL. Lipid antioxidant activity in tissues and proteins of selenium fed animals. $J$ Nutrit $1963 ; 79: 493-502$.

10 Gaunt IF, Grasso P, Gangolli SD. Brominated maize oil. 1. Short term toxicity and bromine storage studies in rats fed brominated maize oil. Food Cosmet Toxicol 1971;9:1-11.

${ }^{11}$ Anderson WAD. Pathology. 5th edn. St Louis: Mosby, 1966.

Requests for reprints to: Dr $\mathbf{H}$ Smith, Department of Forensic Medicine and Science, University of Glasgow, Glasgow G12 8QQ. 